\title{
In the Matter of
}

\section{J. Robert Oppenheimer}




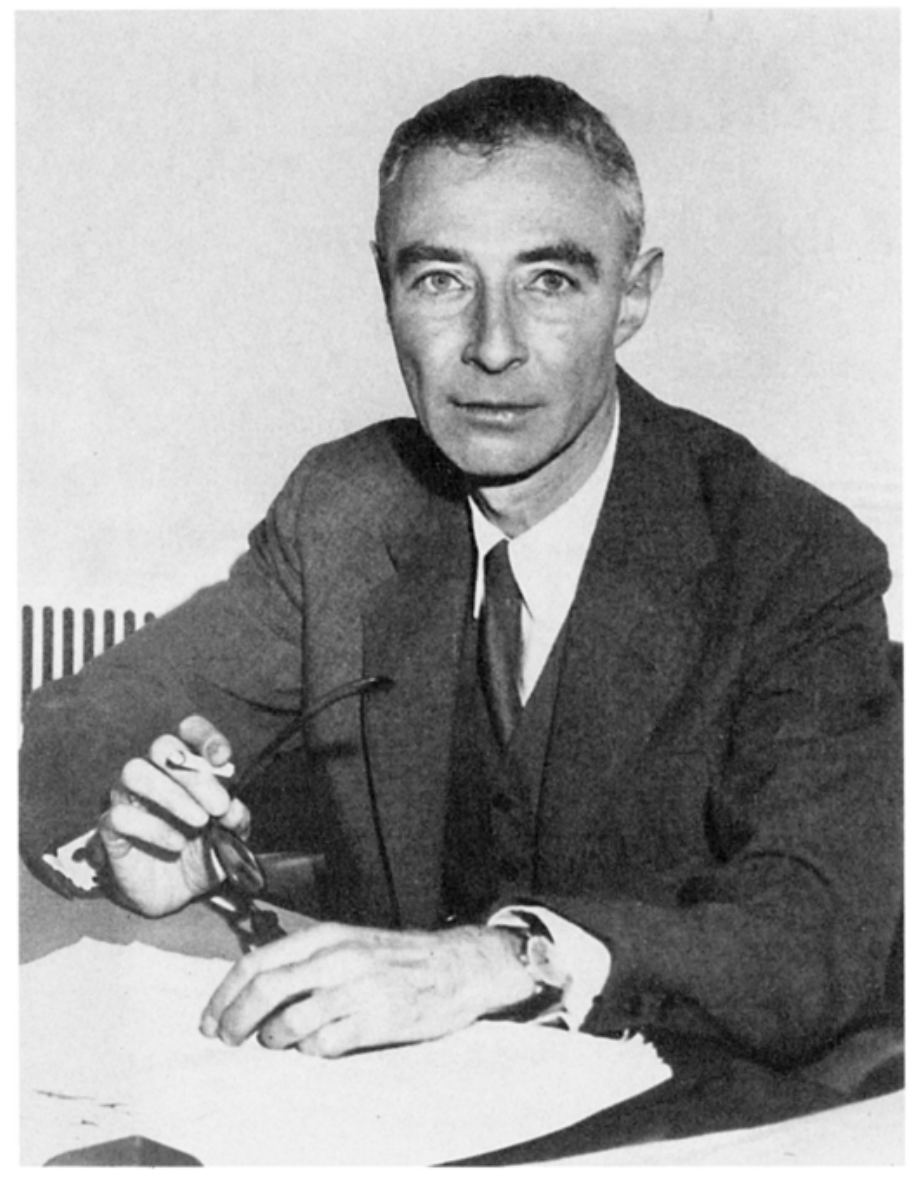

J. Robert Oppenheimer. Reproduced from the Collections of the Library of Congress. 
IN THE MATTER OF

\section{J. Robert Oppenheimer}

THE SECURITY CLEARANCE HEARING

Edited by Richard Polenberg

Cornell University Press Ithaca and London 
Copyright $(\mathcal{O} 2002$ by Cornell University

All rights reserved. Except for brief quotations in a review, this book, or parts thereof, must not be reproduced in any form without permission in writing from the publisher. For information, address Cornell University Press, Sage House, 512 East State Street, Ithaca, New York 14850.

First published 2002 by Cornell University Press

First printing, Cornell Paperbacks, 2002

Printed in the United States of America

\section{LIBRARY OF CONGRESS CATALOGING-IN-PUBLICATION DATA}

In the matter of $\mathrm{J}$. Robert Oppenheimer : the security clearance hearing / edited by Richard Polenberg.

$$
\text { p. cm. }
$$

Includes bibliographical references and index.

ISBN 0-8014-3783-0 (cloth) - ISBN 0-8014-8661-0 (pbk.)

1. Oppenheimer, J. Robert, 1904-1967-Trials, litigation, etc. 2. Hydrogen bomb-History. 3. Internal security—United States. 4. United States-Politics and government-1953-1961. 5. Physicists-United States--Biography. I. Polenberg, Richard.

QC16.062 152002

$530^{\prime} .092-\mathrm{dc} 21$

Cornell University Press strives to use environmentally responsible suppliers and materials to the fullest extent possible in the publishing of its books. Such materials include vegetable-based, lowVOC inks and acid-free papers that are recycled, totally chlorinefree, or partly composed of nonwood fibers. Books that bear the logo of the FSC (Forest Stewardship Council) use paper taken from forests that have been inspected and certified as meeting the highest standards for environmental and social responsibility. For further information, visit our website at www.cornellpress.cornell.edu.

$\begin{array}{lllllllllll}\text { Cloth printing } & 10 & 9 & 8 & 7 & 6 & 5 & 4 & 3 & 2 & 1 \\ \text { Paperback printing } & 10 & 9 & 8 & 7 & 6 & 5 & 4 & 3 & 2 & 1\end{array}$

